\title{
EXTRACTION OF STRONTIUM(II) BY CROWN ETHER: INSIGHTS FROM DENSITY FUNCTIONAL CALCULATION
}

\author{
Saprizal Hadisaputra ${ }^{1,2,}$, Harno Dwi Pranowo ${ }^{2}$, and Ria Armunanto ${ }^{3}$ \\ ${ }^{1}$ Faculty of Teacher Training and Science Education, Mataram University, \\ Jalan Majapahit 62, Mataram 83251 Indonesia \\ ${ }^{2}$ Austrian Indonesian Centre for Computational Chemistry, Universitas Gadjah Mada, \\ Sekip Utara, Yogyakarta 55281 Indonesia
}

Received August 8, 2012; Accepted September 18, 2012

\begin{abstract}
The structures, energetic and thermodynamic parameters of crown ethers with different cavity size, electron donating/withdrawing substituent groups and donor atoms have been determined with density functional method at $B 3 L Y P$ level of theory in gas and solvent phase. Small core quasi-relativistic effective core potentials was used together with the accompanying SDD basis set for $\mathrm{Sr}^{2+}$ and DZP basis set was used for crown ether atoms. Natural bond orbital (NBO) analysis was evaluated to characterize the distribution of electrons on the complexes. The interaction energy is well correlated with the values of Strontium charge after complexation, the second order interaction energies $\left(E_{2}\right)$ and HOMO-LUMO energy gab $\left(\Delta E_{\text {gab }}\right)$. The interaction energy and thermodynamics parameters in gas phase are reduced in solvent phase as the solvent molecules weaken the metal-crown ether interaction. The thermodynamic parameters indicated that less feasibility to extract $\mathrm{Sr}^{2+}$ ion directly from pure water without presence of organic solvent. The theoretical values of extraction energy for $\operatorname{Sr}\left(\mathrm{NO}_{3}\right)_{2}$ salt from aqueous solution in different organic solvent is validated by the experimental trend. This study would have strong contribution in planning the experiments to the design of specific host ligand and screening of solvent for extraction of metal ion.
\end{abstract}

Keywords: strontium; crown ether; density functional theory (DFT)

\section{ABSTRAK}

Telah dilakukan penelitian terhadap variasi ukuran kavitas, substituen gugus penarik dan penerima elektron dan atom donor terhadap parameter struktur, energitika dan termodinamika dari eter mahkota menggunakan metode DFT/B3LYP pada fasa gas dan larutan. Small core quasi-relativistic effective core potentials dengan basis set SDD diaplikasikan untuk $\mathrm{Sr}^{2+}$ dan basis set DZP untuk atom-atom eter mahkota. Hasil analisa natural bond orbital (NBO) telah dievaluasi untuk karakterisasi distribusi elektron pada molekul kompleks. Terdapat korelasi yang baik antara energi interaksi dengan muatan Stronsium setelah terbentuk kompleks, second order interaction energy $\left(E_{2}\right)$ and selisih energi HOMO-LUMO $\left(\Delta E_{g a b}\right)$. Energi interaksi dan parameter termodinamika fasa gas menjadi menurun pada fasa larutan akibat pengaruh molekul pelarut yang melemahkan interaksi ion logam-eter mahkota. Parameter termodinamika menunjukkan sangat kecil kemungkinan melakukan ekstraksi $\mathrm{Sr}^{2+}$ secara langsung dari air murni tanpa kehadiran pelarut organik. Kajian teoritis energi ekstraksi garam $\operatorname{Sr}\left(\mathrm{NO}_{3}\right)_{2}$ dari larutan berair dengan variasi pelarut organik telah divalidasi oleh hasil eksperimen. Kajian ini akan berkontribusi pada perencanaan ekperimen untuk mendesain ligan dan memilih pelarut yang cocok pada ekstraksi ion logam.

Kata Kunci: stronsium; eter mahkota; density functional theory (DFT)

\section{INTRODUCTION}

In nature Strontium $(\mathrm{Sr})$ has several isotopes such as ${ }^{85} \mathrm{Sr},{ }^{87} \mathrm{Sr},{ }^{89} \mathrm{Sr}$ and ${ }^{90} \mathrm{Sr}$. Each individual isotope has applications in the biomedical industry and nuclear science. ${ }^{85} \mathrm{Sr}$ has been used in measuring bone mineralization, in addition, it also used as cancer therapeutic for relief of bone pain and radiologic imagine of bone. Meanwhile, ${ }^{89} \mathrm{Sr}$ has been reported as treatment of painful osseous metastases from breast cancer. ${ }^{90} \mathrm{Sr}$ is also widely used in medical radiotherapy, especially for bone cancer, but it is also used for the radioactive tracer in the field of medicine and agriculture [1-2]. Unfortunately these radioisotopes also pose a threat of dangerous radioactive waste. Keeping Strontium radioisotope as individual radionuclide which is not mixed with other radioisotope is important due to it can reduce the problem of waste disposal. Several

* Corresponding author.

Email address : saprizal.h@gmail.com 
strontium isotope separation techniques have been developed and tested. In the initial context, the use of crown ethers has gained intensive interest which has been used recently as a promising agent to separate the mixture of different radioisotopes [3].

Crown ethers [4] have been recognized as a highly selective compound to interact with metal ions. The interaction of crown ether with metal ion arises due to the interaction of charge (metal ion) and dipole (arises from the donor atom in crown ether). The concept of fit/misfit between the size of the diameter of the metal ion and the cavity of the crown ether is one of the factors that determine the selectivity of crown ethers to metal ions. The next factor is the presence of electrostatic induction effect as additional of electron withdrawing/donating groups within crown ether. Furthermore, altering types of heteroatoms $(\mathrm{O}, \mathrm{N}, \mathrm{S}$ and $\mathrm{P})$ within crown ether and types of solvents (solvation) have crucial role during the extraction process. Solvent plays an important role in changing the host-guest interactions and therefore control the metal ion selectivity.

Different types of electron donating and withdrawing substituents have been incorporated into benzo unit of benzo-18-crown-6. These substituents were introduced to modify the electronic, solubility and other properties of the crown ethers. Among these substituents are alkyl groups, such as methyl, nitro and amine groups and halogen [5]. They were used in the extraction of metal ions including that correlated with nuclear wastes such as cesium and strontium radioisotopes [6]. Furthermore, since the synthesis of aza-18-crown-6 was reported by Greene [7], serial azacrown ethers and diazacrown ethers have been synthesized and their properties to bind metal ions have been described. Futhermore, triazacrown ether, tetrazacrown ether, pentazacrown ether, and hexazacrown ether have also been synthesized. Different types of crown ether derivatives lead to unlimited possibility of using these crown compounds for extraction of metal ion.

The theoretical investigation has been significantly helpful to explain the mechanism of selective capture metal ions by crown ether. Studies have been performed on the effect of cavity size, microsolvation and substitution on the metal ion-crown ether interaction for metal ion selectivity [8-11]. Recently, inclusion of $\mathrm{Cs}^{+}$ and $\mathrm{Sr}^{2+}$ within the cavity of different size crown ethers including benzo-18-crown-6 has been reported using B3LYP/cc-PVTZ and cc-PVDZ level of theory together with a split valence basis set [12]. The structures of azacown and its complexes with alkaline ion in solvent has been reported at B3LYP/6-31 $\mathrm{G}^{* *} / / \mathrm{RHF} / 6-31-\mathrm{G}^{*}$ level of theory [13]. The selectivity of crown ether with different donor atom (N, P and $\mathrm{S}$ ) toward $\mathrm{Li}^{+}, \mathrm{Na}^{+}, \mathrm{Be}^{2+}$ has been studied at B3LYP/6-31+G** level of theory [14-15]. In the current work, we use density functional theory (DFT) to study: (1) effect of cavity size on the structure and interaction of crown ether with $\mathrm{Sr}^{2+}$ (2) effect of electron withdrawing and donating substituents on the structure and energy (3) effect of donor atoms (4) extraction possibility of crown ether in water and solubility of the crown ether in water (5) solvent effect on the extraction process in biphasic system. This computational chemistry approach attempts to design and screening ligand and solvent for $\mathrm{Sr}^{2+}$ extraction from aqueous solution.

\section{COMPUTATIONAL DETAILS}

All calculations were based on approximate DFT in the form of Becke's 1988 exchange functional, combined with the Lee-Yang-Parr correlation functional in the hybrid B3LYP functional. Geometry optimizations have been performed without any symmetry constraints. Optimized geometries are always verified as minima on the potential energy surface by calculating the harmonic vibration frequencies. Tight criteria were used for geometry optimization and numerical DFT integration. Quasi-relativistic ECP include 28 electrons in the core leaving 10 valence electrons and SDD basis set corresponding to the ECP was used for Strontium. For ligand atoms, DZP basis set was used. The basis set superposition errors (BSSE) was eliminated with the counterpoise (CP) method.

Solvent effects are included using the polarized continuum model (PCM) as implemented in the Gaussian code. The dielectric constant for the water solvent was taken as 78.4 and other solvents were used as in Gaussian code. In employing PCM model, the single-point calculations on gas-phase geometries are sufficient for energetics. Structure reoptimization in the presence of the solvent was found to have a minor influence on energetic [16]. Therefore, the single point approach has been employed in this study, for it allows minimizing computational costs without sacrificing much accuracy in solvation energies.

\section{RESULT AND DISCUSSION}

\section{Geometry Parameters}

One of the influece factors that determine the extraction selectivity of crown ether is the best fit between the crown ether cavity and the metal ion diameter. To test the compatibility parameter between cation diameter and crown ether cavity, the 12-crown-4, 15-crown-5, 18-crown-6 and 21-crown-7 


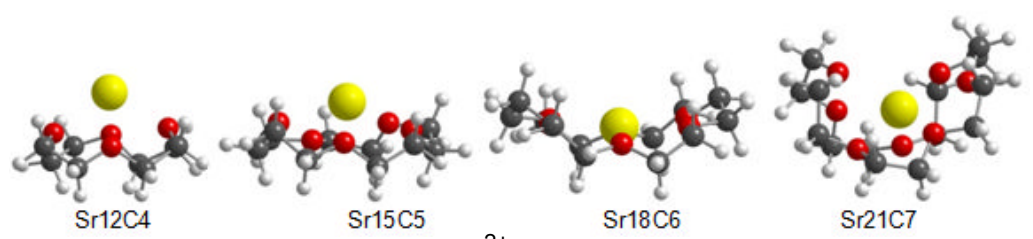

Fig 1. Fully optimized minimum energy structures of $\mathrm{Sr}^{2+}$-crown ether complexes B3LYP level of theory using SDD basis set correspond to small core ECP

Table 1. Selected geometrical parameters of free crown ether, B18C6-R, azacrowns, SrB18C6-R and Sr-azacrowns complexes at the same level of theory as in Fig. 1.

\begin{tabular}{|c|c|c|c|c|c|c|}
\hline \multirow{2}{*}{$\begin{array}{c}\text { System CE and } \mathrm{Sr}^{2+}- \\
\mathrm{CE}\end{array}$} & \multicolumn{2}{|c|}{$\begin{array}{l}\text { O-O diagonal distance } \\
\text { free crown ether }\end{array}$} & \multicolumn{2}{|c|}{$\begin{array}{c}\mathrm{O}-\mathrm{O} / \mathrm{N} \text { diagonal distance } \\
\mathrm{Sr}^{2+} \text {-crown ether }\end{array}$} & \multirow{2}{*}{$\begin{array}{c}\text { Average } \\
\text { cavity size } \\
\text { calculated } \\
\AA\end{array}$} & \multirow{2}{*}{$\begin{array}{c}\text { Average } \\
\text { cavity size } \\
\text { experiment } \\
\AA\end{array}$} \\
\hline & $\operatorname{Min}(\AA \AA)$ & $\operatorname{Max}(\AA))$ & $\operatorname{Min}(\AA \AA)$ & $\operatorname{Max}(\AA)$ & & \\
\hline $12 \mathrm{C} 4$ & 3.34 & 3.34 & 3.57 & 4.11 & 1.54 & $1.2-1.5$ \\
\hline $15 \mathrm{C} 5$ & 4.63 & 5.25 & 4.38 & 4.55 & 2.32 & $1.7-2.2$ \\
\hline $18 \mathrm{C} 6$ & 5.85 & 5.87 & 5.43 & 5.44 & 2.81 & $2.6-3.2$ \\
\hline $21 \mathrm{C} 7$ & 6.06 & 6.95 & 4.66 & 5.34 & 3.82 & $3.4-4.2$ \\
\hline B18C6-NH 2 & 4.82 & 5.62 & 4.71 & 5.22 & 2.66 & \\
\hline $\mathrm{B} 18 \mathrm{C} 6-\mathrm{COOH}$ & 4.78 & 5.61 & 4.79 & 5.21 & 2.66 & \\
\hline $\mathrm{B} 18 \mathrm{C} 6-\mathrm{CH}=\mathrm{CH}_{2}$ & 4.80 & 5.61 & 4.75 & 5.21 & 2.64 & \\
\hline B18C6-OH & 4.82 & 5.61 & 4.72 & 5.22 & 2.65 & \\
\hline $\mathrm{B} 18 \mathrm{C} 6-\mathrm{CH}_{3}$ & 4.80 & 5.62 & 4.76 & 5.21 & 2.65 & \\
\hline $\mathrm{B} 18 \mathrm{C} 6-\mathrm{OCH}_{3}$ & 5.48 & 5.61 & 4.72 & 5.22 & 2.78 & \\
\hline B18C6 & 4.76 & 5.77 & 4.78 & 5.21 & 2.69 & \\
\hline B18C6-F & 5.45 & 5.60 & 4.76 & 5.22 & 2.77 & \\
\hline N1 & 5.79 & 5.83 & 5.35 & 5.41 & 2.68 & \\
\hline N2 & 5.77 & 5.80 & 5.45 & 5.65 & 2.76 & \\
\hline N3 & 5.79 & 5.79 & 4.09 & 5.23 & 2.42 & \\
\hline N4 & 5.62 & 6.17 & 5.01 & 5.06 & 2.55 & \\
\hline N5 & 5.65 & 5.93 & 5.04 & 5.16 & 2.54 & \\
\hline N6 & 5.62 & 5.66 & 5.05 & 5.35 & 2.57 & \\
\hline
\end{tabular}

were calculated and tested to $\mathrm{Sr}^{2+}$ metal ion. From Fig. 1 it can be seen that the diameter of the cavity of 12-crown-4 $(1.54 \AA)$ is much smaller than the diameter of $\mathrm{Sr}^{2+}(2.26 \AA)$ so that the position of $\mathrm{Sr}^{2+}$ ions are in the top plane of 12-crown-4. The same phenomena occurs for 15-crown-5 (2.32 $\AA$ ) with smaller diameter than the diameter of $\mathrm{Sr}^{2+}$, thus $\mathrm{Sr}^{2+}$ position is still on the top plane of 15-crown-5. Furthermore, it shows that $\mathrm{Sr}^{2+}$ pose itself in fully encapsulated position in the middle of the cavity 18 -crown-6 $(2.81 \AA)$. This indicates that $\mathrm{Sr}^{2+}$ is suitable for interacting with the 18-crown-6. The 21-crown-7 shows folding structure during interaction with $\mathrm{Sr}^{2+}$ ion. It can be easily understood from the cavity diameter of 21-crown-7 (3.82 $\AA$ ) is much larger than the diameter of $\mathrm{Sr}^{2+}$ ion. From the result of best fit/misfit between the cavity size of crown ether and metal ion diameter, then we focus to assess in more detail about extraction capability of 18 -crown-6 and its derivatives to $\mathrm{Sr}^{2+}$ ion.

The crown ether cavity size is increased with the enhancement in the ring size from $12 \mathrm{C} 4$ to $21 \mathrm{C} 7$. The calculated average cavity sizes of 12C4, 15C5, 18C6 and $21 \mathrm{C} 7$ are in good agreement with the experimental value. Table 1 shows that the average cavity size calculated have a good agreement with the results of experiments. In the calculation results, the calculated average cavity size of 12 -crown-4 and 15 -crown-5 is slightly larger than the results of experiments by 0.04 and $0.1 \AA$ but for the 18-crown- 6 and 21 -crown-7 have good correlation with the experiments. Changes in the size of the free crown ether cavity are evidently occurred in the addition of benzene rings in 18-crown-6. Crown ether cavity size is reduced about $9.43 \%$ when benzene ring was added to 18 -crown-6. Additional benzene may reduce the flexibility of 18-crown-6 while increase its rigidity. Changing the oxygen atom by nitrogen atoms in the 18-crown- 6 cavity makes the size of crown ether cavity decrease by $8.65 \%$. Order of the decreasing of cavity size of the crown ether are 18-crown-6, benzo-18-crown-6 followed by azacrowns. After complexation reaction occurs, the average cavity sizes of crown ether reduce due to interaction between donor atoms and $\mathrm{Sr}^{2+}$.

Next step, the different types of mono substituted benzo-18-crown-6 and azacrowns have been studied. Electron donating and withdrawing substituents 
Table 2. Geometrical parameter of SrB18C6-R and azacrowns coordinated with 6 oxygen atoms of crown ether at B3LYP level of theory using SDD basis set correspond to small core ECP

\begin{tabular}{lccccc}
\hline B18C6-R & $\begin{array}{c}\text { Bond } \\
\text { Sr-O } \\
\min (\AA)\end{array}$ & $\begin{array}{c}\text { Bond } \\
\text { Sr-O } \\
\max (\AA)\end{array}$ & $\begin{array}{c}\text { Nitrogen } \\
\text { number }\end{array}$ & $\begin{array}{c}\text { Bond } \\
\mathrm{Sr}-\mathrm{O} / \mathrm{N} \\
\min (\AA)\end{array}$ & $\begin{array}{c}\text { Bond } \\
\mathrm{Sr}-\mathrm{O} / \mathrm{N} \\
\max (\AA)\end{array}$ \\
\hline$-\mathrm{NH}_{2}$ & 2.578 & 2.626 & $\mathrm{~N} 0(18 \mathrm{C} 6)$ & 2.642 & 2.647 \\
$-\mathrm{COOH}$ & 2.583 & 2.628 & $\mathrm{~N} 1$ & 2.667 & 2.821 \\
$-\mathrm{CH}=\mathrm{CH}_{2}$ & 2.578 & 2.621 & $\mathrm{~N} 2$ & 2.725 & 2.828 \\
$-\mathrm{OH}$ & 2.577 & 2.627 & $\mathrm{~N} 3$ & 2.492 & 2.754 \\
$-\mathrm{CH}_{3}$ & 2.578 & 2.610 & $\mathrm{~N} 4$ & 2.525 & 2.728 \\
$-\mathrm{OCH}_{3}$ & 2.576 & 2.620 & $\mathrm{~N} 5$ & 2.536 & 2.743 \\
$-\mathrm{H}$ & 2.583 & 2.624 & $\mathrm{~N} 6$ & 2.680 & 2.775 \\
$-\mathrm{F}$ & 2.577 & 2.638 & - & - & - \\
\hline
\end{tabular}

Table 3. Calculated interaction energies $\Delta \mathrm{E}\left(\mathrm{kcal}^{\mathrm{mol}}{ }^{-1}\right)$, the interaction energies corrected by BSSE $\left(\Delta \mathrm{E}_{\mathrm{BSSE}}\right)$, enthalpies $\Delta \mathrm{H}\left(\mathrm{kcal}^{\mathrm{mol}}{ }^{-1}\right)$ and Gibbs free energies $\Delta \mathrm{G}\left(\mathrm{kcal}^{\mathrm{mol}}{ }^{-1}\right)$ in gas phase for the SrB18C6-R complexes at $298 \mathrm{~K}$

\begin{tabular}{lccccc}
\hline \multicolumn{1}{c}{ SrB18C6-R } & $\Delta E$ & $B S S E$ & $\Delta E_{B S S E}$ & $\Delta H$ & $\Delta G$ \\
\hline$-\mathrm{COOH}$ & -225.88 & 4.18 & -221.70 & -209.05 & -198.06 \\
$-\mathrm{F}$ & -226.52 & 5.12 & -221.40 & -209.94 & -198.79 \\
$-\mathrm{H}$ & -230.96 & 5.17 & -225.79 & -214.62 & -202.57 \\
$-\mathrm{CHCH}$ & -231.91 & 5.10 & -226.80 & -215.28 & -204.32 \\
$-\mathrm{OH}$ & -232.94 & 5.13 & -227.80 & -216.12 & -253.85 \\
$-\mathrm{CH}_{3}$ & -233.33 & 5.15 & -228.17 & -228.70 & -267.78 \\
$-\mathrm{OCH}_{3}$ & -235.14 & 5.10 & -230.04 & -203.78 & -243.37 \\
$-\mathrm{NH}_{2}$ & -237.87 & 5.08 & -232.78 & -233.26 & -221.85 \\
\hline
\end{tabular}

Table 4. Calculated interaction energies $\Delta \mathrm{E}\left(\mathrm{kcal}_{\mathrm{mol}}{ }^{-1}\right)$, the interaction energies corrected by $\mathrm{BSSE}\left(\Delta \mathrm{E}_{\mathrm{BSSE}}\right)$, enthalpies $\Delta \mathrm{H}\left(\mathrm{kcal}^{\mathrm{mol}}{ }^{-1}\right)$ and Gibbs free energies $\Delta \mathrm{G}\left(\mathrm{kcal}^{\mathrm{mol}}{ }^{-1}\right)$ in gas phase for the Sr-azacrowns complexes at $298 \mathrm{~K}$

\begin{tabular}{cccccc}
\hline Complexes & $\Delta E$ & $B S S E$ & $\Delta E_{B S S E}$ & $\Delta H$ & $\Delta G$ \\
\hline N0 & -234.85 & 6.13 & -228.71 & -212.54 & -202.55 \\
N1 & -239.64 & 5.70 & -233.94 & -209.05 & -209.15 \\
N2 & -240.00 & 5.15 & -234.85 & -208.92 & -197.59 \\
N3 & -250.38 & 5.23 & -245.14 & -207.13 & -195.39 \\
N4 & -254.47 & 5.50 & -248.96 & -213.12 & -201.23 \\
N5 & -256.59 & 5.09 & -251.49 & -214.74 & -203.22 \\
N6 & -258.41 & 6.13 & -252.28 & -211.30 & -207.18 \\
\hline
\end{tabular}

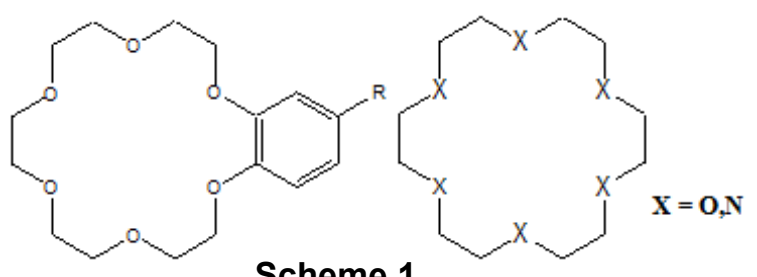

Scheme 1

$\left(\mathrm{R}=-\mathrm{H}=\mathrm{CH}_{2},-\mathrm{OH},-\mathrm{CH}_{3},-\mathrm{OCH}_{3},-\mathrm{CHO},-\mathrm{COOH},-\mathrm{F}\right.$, $-\mathrm{NH} 2$ ) were added into benzo unit of benzo-18-crown-6 and nitrogen atoms were replaced oxygen in the 18-crown-6 ring as depicted in Scheme 1.

The selective minimum and maximum bond lengths of $\mathrm{Sr}^{2+}-\mathrm{O}$ and $\mathrm{Sr}^{2+}-\mathrm{O} / \mathrm{N}$ in the complexes are slightly changes. Bond length of $\mathrm{Sr}^{2+}-\mathrm{O}$ on benzo-18-crown-6 and its derivatives is $2.576 \AA-2.638 \AA$ while for azacrowns the bond length is $2.492 \AA-2.828 \AA$ (Table 2 ). The changes in bond length can be used as the preliminary prediction of the strength of crown ether or the strength of interaction between the metal ions and crown ethers. From Table 2 can be seen that the minimum bond length of azacrown is shorter than that of benzo-18-crown-6. Thus, it is predicted that $\mathrm{Sr}^{2+}$ interacts more strongly with azacrown than with benzo18-crown-6 and its derivatives.

\section{Energy and Thermodynamics Parameters}

Generally, the interaction energy is related to the stability of the complexes. The interaction energies for the metal ion (M) and crown ether (CE) complexes were calculated as the energy difference between the complexes and their monomer. The interaction energies were also corrected for the undesirable effects of basis set superposition error (BSSE) using the counterpoise method. For the interaction in the 
Table 5. The maximum second-order interaction energies $E_{2}\left(\mathrm{kcal}^{\mathrm{mol}}{ }^{-1}\right)$, the energy values of $E_{\text {Hомо }}, E_{\text {LUMO }}$, energy gap $\Delta \mathrm{E}$ and minimum and maximum frequency of SrB18C6-R complexes

\begin{tabular}{|c|c|c|c|c|c|c|c|c|}
\hline Complexes & NBO donor & NBO acceptor & E2 & $\mathrm{E}_{\text {номо }}$ & $E_{\text {LUMO }}$ & $\Delta \mathrm{Egab}$ & Freq min & Freq max \\
\hline$-\mathrm{COOH}$ & LP1O26 & $\mathrm{LP}^{*} \mathrm{Sr} 46$ & 3.08 & -12.18 & -7.22 & 4.97 & 21.25 & 3764.48 \\
\hline$-F$ & LP1O26 & $\mathrm{LP}^{*} \mathrm{Sr} 46$ & 3.11 & -12.12 & -7.23 & 4.89 & 24.85 & 3245.22 \\
\hline$-H$ & LP1O26 & $\mathrm{LP}^{*} \mathrm{Sr} 46$ & 3.08 & -12.12 & -7.15 & 4.96 & 25.78 & 3238.21 \\
\hline$-\mathrm{CHCH}_{2}$ & LP1O26 & $\mathrm{LP}^{*} \mathrm{Sr} 46$ & 3.11 & -11.04 & -7.07 & 3.98 & 21.94 & 3270.14 \\
\hline$-\mathrm{OH}$ & LP1O26 & $\mathrm{LP}^{*} \mathrm{Sr} 46$ & 3.14 & -11.47 & -7.08 & 4.39 & 24.81 & 3830.15 \\
\hline$-\mathrm{CH}_{3}$ & LP1O26 & $\mathrm{LP}^{*} \mathrm{Sr} 46$ & 3.10 & -11.78 & -7.08 & 4.71 & 24.11 & 3222.51 \\
\hline$-\mathrm{OCH}_{3}$ & LP1O26 & $\mathrm{LP}^{*} \mathrm{Sr} 46$ & 3.14 & -11.19 & -7.02 & 4.17 & 25.35 & 3249.23 \\
\hline$-\mathrm{NH}_{2}$ & LP1O26 & $\mathrm{LP}^{*} \mathrm{Sr} 46$ & 3.14 & -10.67 & -6.96 & 3.72 & 25.05 & 3746.00 \\
\hline
\end{tabular}

Table 6. The maximum second-order interaction energies $E_{2}\left(\mathrm{kcal}^{\mathrm{mol}}{ }^{-1}\right)$, the energy values of $E_{\text {HOMO }}$, $E_{\mathrm{LUMO}}$, energy gap $\triangle \mathrm{E}$ and minimum and maximum frequency of Sr-azacrowns complexes

\begin{tabular}{|c|c|c|c|c|c|c|c|c|}
\hline Complexes & NBO donor & NBO acceptor & E2 & $\mathrm{E}_{\text {HOMO }}$ & $\mathrm{E}_{\text {LUMO }}$ & $\Delta$ Egab & Freq min & Freq max \\
\hline No & LP1038 & $\mathrm{LP} * \mathrm{Sr} 43$ & 2.94 & -13.95 & -7.37 & 6.58 & 11.18 & 3129.85 \\
\hline N1 & LP1N39 & LP*Sr42 & 3.18 & -13.70 & -7.13 & 6.57 & 21.64 & 3528.07 \\
\hline N2 & LP1N42 & $\mathrm{LP}{ }^{*} \mathrm{Sr} 41$ & 3.25 & -13.96 & -7.22 & 6.74 & 13.89 & 3529.34 \\
\hline N3 & LP1N40 & $L P^{*} \operatorname{Sr} 39$ & 5.66 & -13.39 & -6.87 & 6.52 & 31.24 & 3523.79 \\
\hline N4 & LP1N39 & $\mathrm{LP} * \mathrm{Sr} 40$ & 5.78 & -13.66 & -6.92 & 6.74 & 34.24 & 3522.00 \\
\hline N5 & LP1N39 & $L P * \operatorname{Sr} 38$ & 6.18 & -13.56 & -6.89 & 6.67 & 34.72 & 3523.06 \\
\hline N6 & LP1N43 & $\mathrm{LP}^{*} \mathrm{Sr} 37$ & 6.49 & -13.39 & -6.87 & 6.52 & 29.99 & 3521.43 \\
\hline
\end{tabular}

system involved, the interaction energy can be expressed as follows:

$\Delta \mathrm{E}=\mathrm{E}_{\mathrm{M}-\mathrm{CE}}-\left(\mathrm{E}_{\mathrm{M}}+\mathrm{E}_{\mathrm{CE}}\right)$

here, $E_{M-C E}$ was the complex energy, $E_{M}$ the energy of metal ions and $E_{C E}$ the energy of crown ether. The calculated interaction energies for the complexes in the gas phase with the absence of solvent molecule are listed in Table 3 and 4.

The interaction energy trend shows that electron donating substituents increase the interaction energies between metal ions and the studied crown ethers (5 - $8 \mathrm{kcal} / \mathrm{mol})$, compared with the unsubstituted benzo18-crown-6. In contrast, electron withdrawing substituents reduce the complex interaction energies about 2 - $7 \mathrm{kcal} / \mathrm{mol}$ from the original unsubstituted benzo-18-crown-6 (Table 3). For benzo-18-crown-6 derivatives, the interaction energies follows the order of $-\mathrm{COOH}<-\mathrm{F}<-\mathrm{H}<-\mathrm{CHCH}_{2}<-\mathrm{OH}<-\mathrm{CH}_{3}<-\mathrm{OCH}_{3}<$ $-\mathrm{NH}_{2}$. Basis set superposition error (BSSE) values are considerably small in this calculation, about $2 \%$ margin from the interaction energies. It is also better than BSSE energy produced from alkaline earth and 12-crown-4 complexes calculated by B3LYP/B3LYP/6-31+G** level of theory [15]. It indicates that the calculation level of theory is suitable for these systems. The enthalpy $(\Delta \mathrm{H})$ and free Gibbs energy $(\Delta G)$ of reaction is strongly negative $(-221.7$ to $-232.7 \mathrm{kcal} / \mathrm{mol})$ which shows that in gas phase $\mathrm{Sr}^{2+}$ interact strongly with crown ether. It is need to be noted that small differences between the interaction energies of electron donating and withdrawing complexes indicate less contribution of these substituents for the complex stability in gas phase.
The interaction energy for the azacrowns system increase as the number of nitrogen atom gradually increased. From Table 4, the interaction energy of NO or $\operatorname{Sr}(18-\text { crown-6) }]^{2+}$ has interaction energy about $-234.85 \mathrm{kcal} / \mathrm{mol}$ but than the interaction energy increase significantly about $24 \mathrm{kcal} / \mathrm{mol}$ for $\mathrm{N} 6$ or $\left[\mathrm{Sr}\left(\right.\right.$ hexaaza-18-crown-6)] ${ }^{2+}(-258.41 \mathrm{kcal} / \mathrm{mol})$. For azacrown complxes, the interaction energies follows the order of $18 \mathrm{C} 6(\mathrm{~N} 0)<\mathrm{N} 1<\mathrm{N} 2<\mathrm{N} 3<\mathrm{N} 4<\mathrm{N} 5<\mathrm{N} 6$. Apparently, the nitrogen number of the 18-membered crown ether plays an important role in the stability of the complexes which perfectly means that the nitrogen number does has significant effect on the $\mathrm{Sr}^{2+}$ binding selectivity in gas phase. The enthalpy $(\Delta \mathrm{H})$ and free Gibbs energy $(\Delta G)$ of reaction for these systems is also negative $(-195.39$ to $-214.74 \mathrm{kcal} / \mathrm{mol})$.

\section{Natural Bond Orbital (NBO) Analysis}

For further study on the effect of substituents and donor atom, the second order interaction energies $\left(E_{2}\right)$ based on the Natural Bond Orbital (NBO) analysis were also calculated. $E_{2}$ corresponds to the intensity of change transfer interaction between Lewis donor and non-Lewis acceptor NBO. For each donor NBO (i) and acceptor NBO (j), $E^{2}$ associated with $i \rightarrow j$ delocalization can be estimated as follows:

$E_{2}=\frac{q_{i} \times F_{(i, j)}}{\left(\varepsilon_{i}-\varepsilon_{j}\right)}$

here, $q_{i}$ is the donor orbital occupancy, $\varepsilon_{i}, \varepsilon_{j}$ are diagonal elements (orbital energies) and $F_{(i, j)}$ are the off diagonal elements of NBO Fox matrix. The $\mathrm{E}_{2}$ obtained 

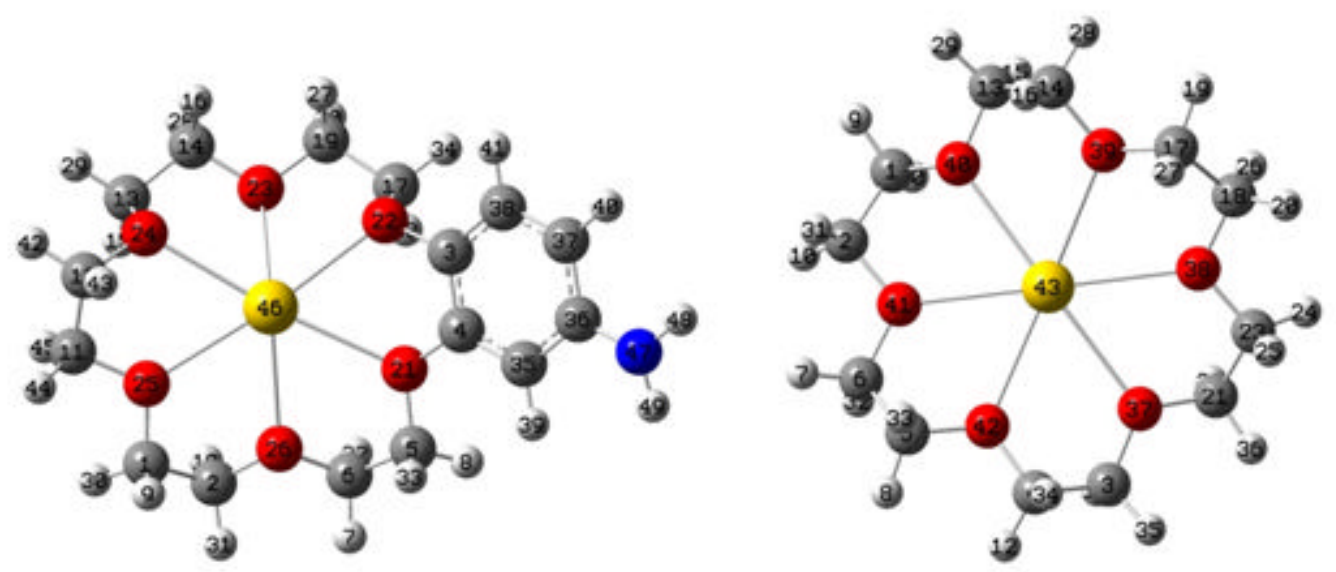

Fig 2. Fully optimized minimum energy structures of $\mathrm{Sr}-\mathrm{B} 18 \mathrm{C} 6-\mathrm{NH}_{2}$ and $\mathrm{Sr}-18-\mathrm{crown}-6$. The atomic label were taken from NBO calculation results

Table 7. The Strontium charges before and after complexation with crown ether studied by Mulliken population analysis (MPA) and Natural population analysis (NPA) from NBO calculation.

\begin{tabular}{lccccccc}
\hline Substituent & $\begin{array}{c}\text { free metal } \\
\text { ion charge } \\
\text { Sr }\end{array}$ & $\begin{array}{c}\text { MPA } \\
\text { charge } \\
\text { Sr }\end{array}$ & $\begin{array}{c}\text { NPA } \\
\text { charge } \\
\text { Sr }\end{array}$ & $\begin{array}{c}\text { Nitrogen } \\
\text { number }\end{array}$ & $\begin{array}{c}\text { free metal } \\
\text { ion } \\
\text { Sr }\end{array}$ & $\begin{array}{c}\text { MPA } \\
\text { charge } \\
\text { Sr }\end{array}$ & $\begin{array}{c}\text { NPA } \\
\text { charge } \\
\text { Sr }\end{array}$ \\
\hline$-\mathrm{COOH}$ & 2.000 & 1.224 & 1.874 & $\mathrm{~N} 0$ & 2.000 & 1.196 & 1.873 \\
$-\mathrm{F}$ & 2.000 & 1.225 & 1.873 & $\mathrm{~N} 1$ & 2.000 & 1.175 & 1.867 \\
$-\mathrm{H}$ & 2.000 & 1.223 & 1.873 & $\mathrm{~N} 2$ & 2.000 & 1.156 & 1.867 \\
$-\mathrm{CHCH}$ & 2.000 & 1.218 & 1.873 & $\mathrm{~N} 3$ & 2.000 & 1.156 & 1.842 \\
$-\mathrm{OH}_{2}$ & 2.000 & 1.220 & 1.873 & $\mathrm{~N} 4$ & 2.000 & 1.094 & 1.829 \\
$-\mathrm{CH}_{3}$ & 2.000 & 1.218 & 1.873 & $\mathrm{~N} 5$ & 2.000 & 1.064 & 1.824 \\
$-\mathrm{OCH}_{3}$ & 2.000 & 1.217 & 1.872 & $\mathrm{~N} 6$ & 2.000 & 1.037 & 1.819 \\
$-\mathrm{NH}_{2}$ & 2.000 & 1.215 & 1.872 & & & & \\
\hline
\end{tabular}

from NBO analysis are shown in Table 5 and 6 . It clearly indicated that the lone pair electron (LP) of oxygen atoms in crown ether and the antibond-lone pair electron $\left(\mathrm{LP}^{*}\right)$ of the $\mathrm{Sr}^{2+}$ is mainly responsible for $\mathrm{E}_{2}$ values. For instant in the case of Sr-B18C6-R, the main contribution for $E_{2}$ is the orbital donor and acceptor from LP oxygen $(\mathrm{O} 26)$ and $\mathrm{LP}^{*} \mathrm{Sr} 46$ as shown in Fig. 2. Similar trend also found for Sr-18C6 where the orbital donor and acceptor from LP oxygen (O38) and LP* $\mathrm{Sr} 43$ contribute more toward $E_{2}$. In term of $E_{2}$ from the NBO analysis in Table 5 and 6, two general conclusions can be taken: (i) the small changes on the $E_{2}$ values for each metal complex series confirm that the electron donating and withdrawing substituents on benzo unit have less appreciable effects on the interaction between $\mathrm{Sr}^{2+}$ with benzo substituted crown ethers in gas phase (ii) the $E_{2}$ values in azacrowns complexes gradually increase as the number of nitrogen atom increase means that the nitrogen number has play important role in the complexes formation in gas phase.

A higher value of ( $\left.\mathrm{E}_{\text {номо }}\right)$ shows a tendency of the molecule to donate electrons to appropriate acceptor molecule of low empty molecular orbital energy. On the other hand, the energy of the lowest unoccupied molecular orbital $\left(E_{\text {LUMO }}\right)$ indicates the ability of the molecule to accept electrons. Larger values of the energy difference, $\Delta \mathrm{E}_{\text {gab }}$ between $\mathrm{E}_{\text {LUMO }}-\mathrm{E}_{\text {HOMO }}$, present low reactivity to a chemical species and hence more stable and lower values of the energy difference show higher reactivity means less stable. From Table 5 and 6 , the $\Delta \mathrm{E}_{\text {gab }}$ of benzo-18-crown-6 and its derivatives have lower values than that of azacrowns which mean that the complexes of $\mathrm{Sr}^{2+}$-benzo-18crown-6 have higher reactivity than azacrown complexes. It can be seen that the $\mathrm{Sr}^{2+}$-benzo-18crown-6 is less stable than that of $\mathrm{Sr}^{2+}$-azacrown complexes. This result has a good correspondence with the interaction energy of the complexes in gas phase. Furthermore, the minimum and maximum wavenumber in frequency calculation shows all positive values which indicates that all complexes are in the global minima potential energy surface.

The values of atomic charge of $\mathrm{Sr}^{2+}$ are listed in Table 7. Here, we use Mulliken population analysis (MPA) and Natural population analysis (NPA) from NBO calculation to study the charge transfer during the formation of the complexes. It is can be observed that the atomic charges of $\mathrm{Sr}^{2+}$ after complexation is in accordance with the interaction energy and the second 


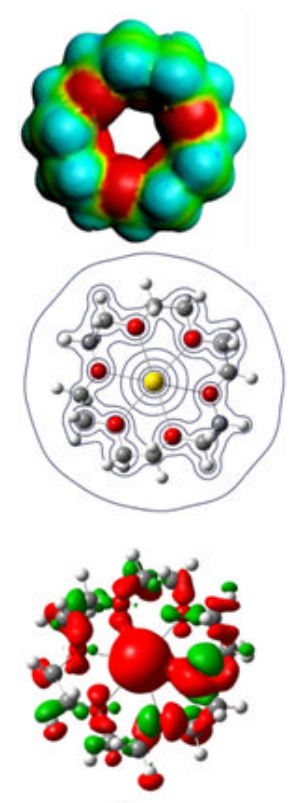

A
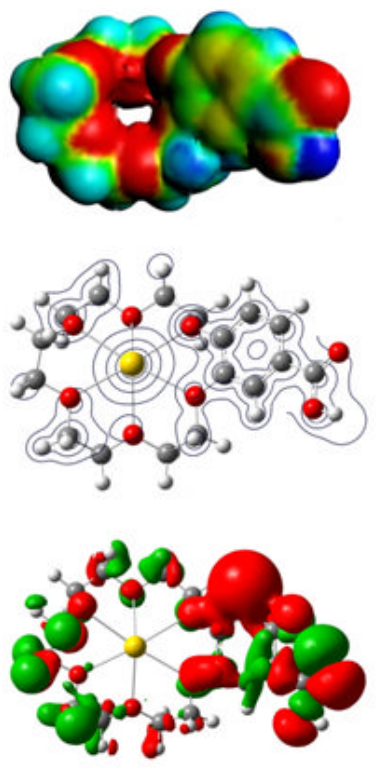

B
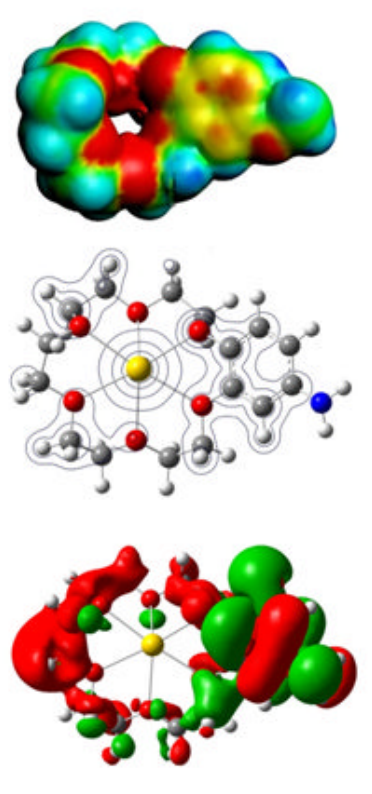

$\mathrm{C}$

Fig 3. A) above, electron density of 18C6; middle, electrostatic potential of Sr18C6; low, HOMO-LUMO orbital of Sr18C6. B) similar order in Fig. 3A with SrB18C6-COOH. C) the same order with Fig. 3A represented by SrB18C6$\mathrm{NH}_{2}$. All NBO results are calculated at BPLYP SDD/DZP level of theory. Red color indicate electron rich region of molecules

order interaction energy $\left(\mathrm{E}_{2}\right)$. The MPA and NPA values are different to each other mean that for charge distributions, there is no perfect method with which to accurately obtain electron populations of atoms. Although different methods lead to different populations, it is expected that the changes of population in uncomplexed and complexed states will be similar for different methods. MPA charge of Strontium after complexation with mono substituted benzo-18-crown-6 are in the range of $1.215-1.225$ while for the NPA they are in the range of $1.972-1.874$. These values are higher than the values from Strontium after complexaton with azacrowns means that azacrown complexes receive more electron transfer from Strontium as a result the interaction energy of this system also higher than the interaction energy of Sr-benzo-18-crown-6 complex system.

In order to give a clear view of the electron distribution on the complexes as a consequence of the existence of electron donating/withdrawing substituents and nitrogen number, the electron density, electrostatic potential and the molecular orbital were calculated as presented in Fig. 3. The electrostatic potential demonstrates the energy of interaction of a positive point charge with the fixed charge distribution of a molecule and the nuclei [17]. The molecular isosurface of electron density, electrostatic potential and molecular orbital indicates the electron rich region of the molecules. Fig. $3 \mathrm{~A}$ shows the electron density, electrostatic potential and molecular orbital of free 18-crown-6 and
Sr-18-crown-6 where the electron rich region of this system concentrate in the central of interaction points. Next, Fig. 3B shows electrostatic potential (blue contour) illustrates that electron withdrawing substituents represented by $\mathrm{Sr}-\mathrm{B} 18 \mathrm{C} 6-\mathrm{COOH}$ where its electron rich region spread out on the molecule, as a result, the ability of crown ether to bind metal ion reduce. However, electron donating substituents $\left(\mathrm{Sr}-\mathrm{B} 18 \mathrm{C} 6-\mathrm{NH}_{2}\right)$ concentrate the electron rich region of the molecule closer into the interaction points (the oxygen atoms of crown ethers), therefore the capability of crown ether to bind ions increase.

\section{Solvent Exchange Reaction}

In order to study the possibility of extracting $\mathrm{Sr}^{2+}$ directly from pure water as a solvent, we used simple model of solvent exchange reaction as shown in equation 3 to gain the enthalpy of reaction $(\Delta H)$ and the reaction free energy $(\Delta G)$. The values of the enthalpy of reaction $(\Delta \mathrm{H})$ and the reaction free energy $(\Delta \mathrm{G})$ in the absence and the presence of the number of water molecules plotted in Fig. 4a-c. From the figure it can be seen that when the number of $\mathrm{H}_{2} \mathrm{O}$ molecule rich 6 molecules which incidentally the first shell coordination number of Strontium ion, all values of $\Delta \mathrm{H}$ is positive. This indicates that the solvent exchange reactions are very difficult to happen. This is strengthened by the values of $\Delta \mathrm{G}$ that tend to be positive. The influence of entropy also affects the ligand exchange reaction is 

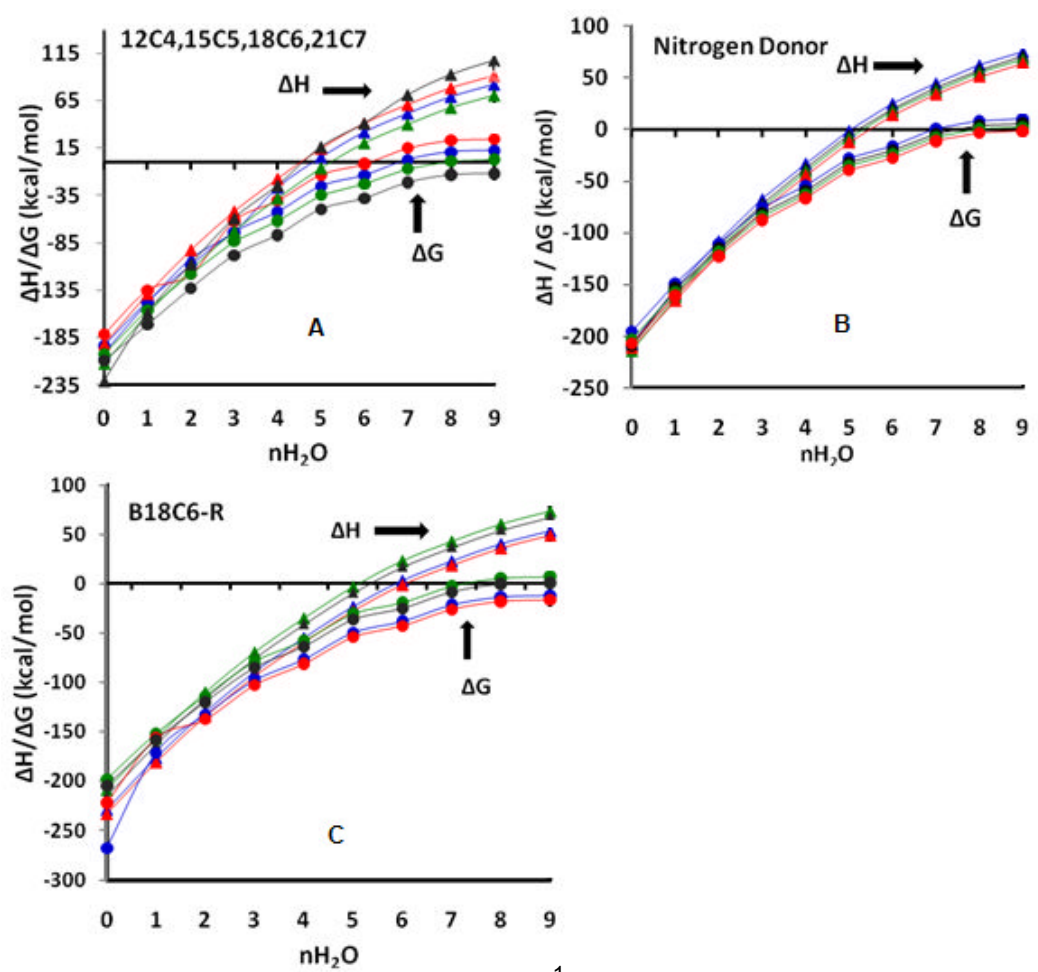

Fig 4. Plot of enthalpy $(\Delta \mathrm{H})$ and free energy $(\Delta \mathrm{G})\left(\mathrm{kcal}^{\mathrm{mol}}{ }^{-1}\right)$ of solvent exchange reaction (Eq. 2) with crown ligand against number of water molecules $\left(\mathrm{nH}_{2} \mathrm{O}, \mathrm{n}=1-9\right)$. A) effect of cavity size (B) effect of donor atom (N0, N2, N4, N6) (C) effect of electron donating and withdrawing susbtituent $\left(-\mathrm{COOH},-\mathrm{F},-\mathrm{CHCH}_{2},-\mathrm{NH}_{2}\right)$

Table 8. Calculated values of aqueous solubility of various crown ligands at B3LYP/DZP level of theory using COSMO-RS formalism at $298 \mathrm{~K}$

\begin{tabular}{lcc}
\hline \multicolumn{1}{c}{ Ligand } & $\begin{array}{c}\text { Calculated } \\
\text { Aqueous } \\
\text { Solubility (g/L) }\end{array}$ & $\begin{array}{c}\text { Experimental } \\
\text { Aqueous } \\
\text { Solubility (g/L) }\end{array}$ \\
\hline B18C6-F & 3.50 & - \\
B18C6-COOH & 4.35 & - \\
B18C6 & 0.99 & - \\
B18C6-CHCH & 0.83 & - \\
B18C6-OH & 7.51 & - \\
B18C6-OCH & 3.17 & - \\
B18C6-CH & 0.98 & - \\
B18C6-NH & 7.55 & - \\
18C6 & 81.7 & 74.5 \\
1-aza-18C6 & 99.3 & soluble \\
hexaaza-18C6 & Large & soluble \\
\hline
\end{tabular}

due to a growing number of water molecules in the system, the higher the degree of freedom or entropy. From this thermodynamics study, it can be concluded that the extraction of $\mathrm{Sr}^{2+}$ using pure water is hardly occurred due to the energy of water solvation of $\mathrm{Sr}^{2+}$ is high.

$$
\mathrm{Sr}\left(\mathrm{H}_{2} \mathrm{O}\right) \mathrm{n}+\mathrm{CE} \rightarrow \mathrm{SrCE}+\mathrm{n} \mathrm{H}_{2} \mathrm{O}
$$

The highest enthalpy of reaction is shown by the azacrowns followed by free substituted crown and the lowest with crown ether substituted benzo-18-crown-6. It is necessary to note that both the enthalpy and free energy of reaction is reduced from the gas phase due to the presence of water as solvent molecules. In the gas phase $\left(\mathrm{nH}_{2} \mathrm{O}=0\right)$ reaction enthalpy ranges between $-185-216 \mathrm{kcal} / \mathrm{mol}$, but as the addition of $\mathrm{H}_{2} \mathrm{O}$ molecule gradually increase, the enthalpy of reaction likely continue to decline even shows positive value $\left(\mathrm{nH}_{2} \mathrm{O}=9\right)$. The similar situation is also found in the change of Gibbs free energy. Furthermore, the greater the number of nitrogen atoms in the crown ether, the more negative enthalpy is and vice versa. The addition of the electron withdrawing groups in benzo-18-crown-6 produces a lower enthalpy and the addition of electron donating groups result in higher enthalpy. Here, also enthalpy becomes positive after six molecules of water but a positive entropy contribution due to release of water molecules during the complexation produces negative free energy, which facilitates the complexation reaction for few benzo-18-crown-6 substituted ether.

\section{Aqueous Solubility}

The solubility of ligand in water plays the important role in the application of it in different solvent extraction based technology. The target ligand should have a low aqueous solubility to have an economical 


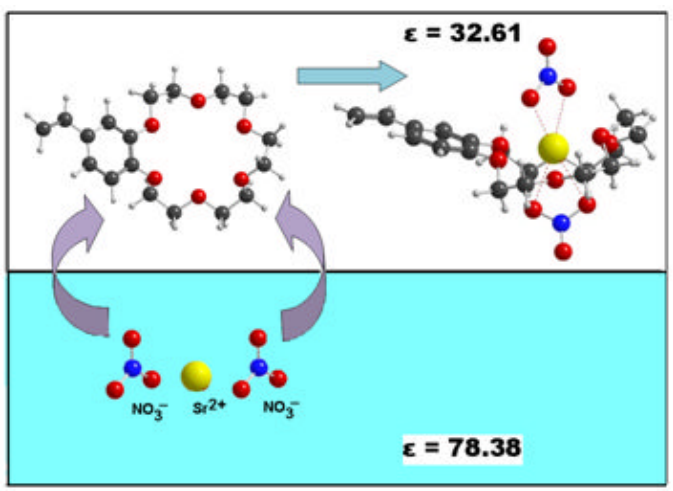

Scheme 2. Illustration of solvent extraction of $\mathrm{Sr}\left(\mathrm{NO}_{3}\right)_{2}^{-}$ by $\mathrm{B} 18 \mathrm{C} 6-\mathrm{CHCH}_{2}$ in biphasic system (water-organic solvents)

Table 9. Calculated interaction energies of $18 \mathrm{C} 6$ and B18C6- $\mathrm{CHCH}_{2}$ in gas phase and solvent environment at B3LYP level of theory using SDD and DZP basis sets at $298 \mathrm{~K}$.

\begin{tabular}{lrc}
\hline Phase & $\Delta \mathbf{E}(\mathrm{Kcal} / \mathbf{m o l})$ & Log $\mathbf{K}(\mathbf{e x p})$ \\
\hline a) $18 \mathrm{C} 6$ & -234.85 & - \\
Gas & -36.98 & $5.31 \pm 0.05$ \\
Acetone & -34.90 & $4.71 \pm 0.06$ \\
Methanol & -33.38 & $4.21 \pm 0.04$ \\
$\mathrm{H}_{2} \mathrm{O} /$ Ethanol & -33.17 & $4.09 \pm 0.06$ \\
$\mathrm{H}_{2} \mathrm{O} /$ Methanol & -33.70 & - \\
$\mathrm{H}_{2} \mathrm{O} /$ benzene & -33.13 & - \\
$\mathrm{H}_{2} \mathrm{O}$ /nitrobenzene & & \\
b) $\mathrm{B} 18 \mathrm{C6}-\mathrm{CHCH}_{2}$ & -231.91 & \\
$\mathrm{GaS}$ & -66.55 & - \\
$\mathrm{H}_{2} \mathrm{O} /$ benzene & -61.02 & - \\
$\mathrm{H}_{2} \mathrm{O} /$ nitrobenzene & & \\
\hline
\end{tabular}

and efficient solvent extraction based process design. The calculated values of solubility of the designed crown ether are tabulated in Table 8. From the table it is seen that the azacrowns have the highest and $\mathrm{B} 18 \mathrm{C} 6-\mathrm{CHCH}_{2}$ has the lowest solubility in water. The solubility follows the order $-\mathrm{B} 18 \mathrm{C} 6-\mathrm{CHCH}_{2}<-\mathrm{CH}_{3}<-\mathrm{H}<-\mathrm{OCH}_{3}<-\mathrm{F}<-$ $\mathrm{COOH}<-\mathrm{OH}<-\mathrm{NH}_{2}<\mathrm{NO}<\mathrm{N} 1<\mathrm{N} 6$. The solubility of $18 \mathrm{C} 6$ is $81.7 \mathrm{~g} / \mathrm{L}$ which closely similar to the experimental value $(74.7 \mathrm{~g} / \mathrm{L})$. The aqueous solubility of $18 \mathrm{C} 6$ is higher than Benzo-18C6 derivatives. Additional benzene ring into 18C6 makes them less soluble in water. Furthermore, adding functional group like $\mathrm{NH}_{2}$, $\mathrm{OH}, \mathrm{COOH}$ and $\mathrm{F}$ into $\mathrm{B} 18 \mathrm{C} 6$ increases the solubility in water, whereas methyl and methylene $\left(-\mathrm{CH}_{3},-\mathrm{CHCH}\right)$ groups decreases the aqueous solubility due to increased hydrophobicity. Hence, B18C6- $\mathrm{CHCH}_{2}$ appears to be the suitable ligand for extraction of $\mathrm{Sr}^{2+}$. The azacrowns shows the opposite result from gas phase interaction. Azacrowns show the highest aqueous solubility, thus the use of these crown ethers in solvent extraction experiment is not recommended.

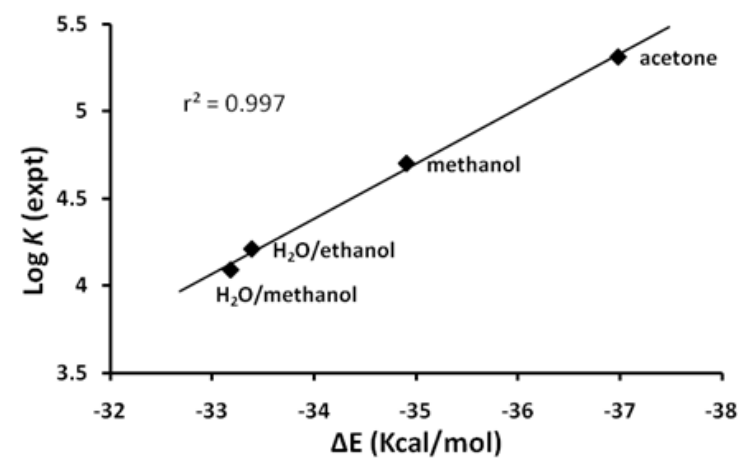

Fig 5. Correlation between the log $K$ values and the interaction energies of $\mathrm{Sr}\left(\mathrm{NO}_{3}\right)_{2}-18-c r o w n-6$ complexes in different solvent environments (acetone, methanol, $\mathrm{H}_{2} \mathrm{O}$ /ethanol and $\mathrm{H}_{2} \mathrm{O}$ /methanol), $\mathrm{r}^{2}=0.997$

Next it would be important to study the extraction properties of these crown ethers as close as possible with the experimental scheme. For this purpose, the solvent extraction reaction for $\mathrm{Sr}\left(\mathrm{NO}_{3}\right)_{2}$ salts from aqueous to organic phase was modeled using the Scheme 2. In this model, two nitrate anions are coordinated directly into Sr-crown ether complexes and formed inner-sphere complexes in biphasic system. The model is inspired from the EXAFS experiment where the $\mathrm{Sr}$ coordination environment does not change as $\mathrm{Sr}(\mathrm{NO} 3)_{2}-18 \mathrm{C} 6$ and $\mathrm{Sr}(\mathrm{NO} 3)_{2}$-DC18C6 when they are prepared by extraction from an aqueous solution of $\mathrm{Sr}\left(\mathrm{NO}_{3}\right)_{2}$ and extracted into 1-octanol [18].

According to Scheme 2, the model reaction in biphasic system is the following reaction:

$$
\mathrm{Sr}^{2+}(\mathrm{aq})+2 \mathrm{NO}_{3}^{-} \text {(aq) }+\mathrm{CE}(\text { org }) \rightarrow \mathrm{CE}-\mathrm{Sr}\left(\mathrm{NO}_{3}\right)_{2} \text { (org) }
$$

Here, we employed Polarized Continuum Model (PCM) where the total energy is calculated as the sum of the energy of the solute, the solvent and the cavity. The interaction energy is then calculated by subtracting the total energy of the complexes with each monomer in different solvent environment. Thus, the interaction energy can be calculated as follows:

$\Delta \mathrm{E}=\mathrm{E}_{\mathrm{CE}-\mathrm{Sr}\left(\mathrm{NO}_{3}\right)_{3}}($ org $)-\left(\mathrm{E}_{\mathrm{Sr}\left(\mathrm{NO}_{3}\right)_{2}}(\mathrm{aq})+\mathrm{E}_{\mathrm{CE}}(\right.$ org $\left.)\right)$

For testing the accuracy of the PCM model then the experimental log $K$ values of $\mathrm{Sr}\left(\mathrm{NO}_{3}\right)_{2}$-18-crown-6 complexes at different solvents are plotted with the calculated interaction energies. Fig. 5 indicate that pure acetone is a better solvent for extraction process of $\mathrm{Sr}^{2+}$ with 18-crown-6 then using pure methanol and mixture of $\mathrm{H}_{2} \mathrm{O}$ /ethanol and $\mathrm{H}_{2} \mathrm{O}$ /methanol. This result shows a good correlation between the experimental log $K$ [19-20] values and the calculated interaction energies with linier relationship, $r^{2}=0.997$.

Solvation causes a significant reduction in interaction energies, values are listed in Table 9. In gas phase the interaction energies are $-234.85 \mathrm{kcal} / \mathrm{mol}$, but then in the presence of solvents the interaction 
energies reduce significantly about $85 \%$ into $-36.98 \mathrm{kcal} / \mathrm{mol}$. Extraction Strontium with 18-crown-6 and azacrown are less recommended due to it has high solubility in water and low interaction energy in solvent phase although in gas phase it interacts strongly with $\mathrm{Sr}^{2+}$ than that of $\mathrm{B} 18 \mathrm{C} 6-\mathrm{CHCH}_{2}$. The trend in interaction energy shows that $\mathrm{B} 18 \mathrm{C} 6-\mathrm{CHCH}_{2}$ come out as the suitable ligand for extraction $\mathrm{Sr}^{2+}$ in biphasic system. It has the lowest aqueous solubility and the highest interaction energy $(-66.5 \mathrm{kcal} / \mathrm{mol})$ in biphasic system. For the solvent, benzene type solvents (nitrobenzene and benzene) are recommended for extraction process but special care should be given more due their carcinogenic effect.

\section{CONCLUSION}

The current work reports the various structural, energetic and thermodynamical parameters for Sr-crown ether complex system at DFT/B3LYP level of theory in gas as well as in solvent phase. The binding energy of Strontium ion depends on the type of cavity size and electron withdrawing and donating functional groups and donor atom in the crown ligand. The best fit cavity size is obtained from 18-crown-6 and its derivatives hence the study focuses on the type of crown ether. The interaction energy and enthalpy are decreased due to the presence of electron withdrawing group in benzene ring and increased as electron donating group as the substituent group. They follow the order of $\mathrm{B} 18 \mathrm{C} 6-\mathrm{COOH}<\mathrm{B} 18 \mathrm{C} 6-$ $\mathrm{F}<\mathrm{B} 18 \mathrm{C} 6<\mathrm{B} 18 \mathrm{C} 6-\mathrm{CHCH}_{2}<\mathrm{B} 18 \mathrm{C} 6-\mathrm{OH}<\mathrm{B} 18 \mathrm{C} 6-$ $\mathrm{CH}_{3}<\mathrm{B} 18 \mathrm{C} 6-\mathrm{OCH}_{3}<\mathrm{B} 18 \mathrm{C} 6-\mathrm{NH}_{2}$. For a change in nitrogen donor atoms the interaction energy is increased as the number of nitrogen atoms increase. The interaction energies follows the order of $18 \mathrm{C} 6$ (N0) $<\mathrm{N} 1$ $<\mathrm{N} 2<\mathrm{N} 3<\mathrm{N} 4<\mathrm{N} 5<\mathrm{N} 6$. The interaction energy is in accordance with Mulliken and Natural charge and the second order interaction energy $\left(E_{2}\right)$ and HOMO-LUMO energy gab $\left(\Delta \mathrm{E}_{\text {gab }}\right)$.

The thermodynamics parameters in term of ligand exchange reaction repeals that no feasibility to extract $\mathrm{S}^{2+}$ ion directly from pure water without presence of organic solvent in biphasic system. It is recommended that $\mathrm{B} 18 \mathrm{C} 6-\mathrm{CHCH}_{2}$ is the suitable extractant for $\mathrm{Sr}^{2+}$ due to it has the lowest solubility in water and the highest interaction energy in solvent environment. It is also found that specific ligand needs specific solvent during extractant. For $\mathrm{B} 18 \mathrm{C} 6-\mathrm{CHCH}_{2}$, the solvent especially benzene type solvents (nitrobenzene and benzene) is recommended for the extraction processes in biphasic system (water-organic). This study would have contribution in designing ligand and types of solvent in wet experimental study.

\section{REFERENCES}

1. Nielsen S.P., 2004, Bone. 35, 3, 583-588.

2. Pandit-Taskar, N., Batraki, M., and Divgi, C.R., 2004, J. Nucl. Med., 45, 8,1358-1365.

3. Grüner, B., Plešek, J., Báča, J., Dozol, J.F., Lamare, V., Císařová, I., Bělohradský, M., and Čáslavský, J., 2002, New J. Chem., 26, 7, 867875.

4. Pedersen, C.J., 1967, J. Am. Chem. Soc., 89, 26, 7017-7036.

5. Pannell, K.H., Yee, W., Lewandos, G.S., and Hambrich, D.C., 1977, J. Am. Chem. Soc., 99, 5, 1457-1461.

6. Todd, T. A., Batcheller, T., Law, J.D., and Herbst, R.S., 2004, Cesium and Strontium Separation Technologies Literature Review, Idaho National Engineering and Environmental Laboratory, INEEL/EXT-04-01895.

7. Greene, R.N., 1972, Tetrahedron Lett., 13, 18,1793-1796.

8. Pranowo, H.D., 2006, Indo. J. Chem., 6, 2, 144149.

9. Varadwaj, P.R., Varadwaj, A., and Marques, H.M., 2011, J. Phys. Chem. A, 115, 22, 5592-5601.

10. Yamin, Pranowo, H.D., and Armunanto, R., 2011, Indo. J. Chem., 11, 1, 106-109.

11. Boda, A., Ali, S.M., Shenoi, M.R.K., Rao, H., and Ghosh, S.K., 2012, J. Mol. Model., 18, 8, 35073522.

12. Boda, A., Ali, S.M., Shenoi, M.R.K., Rao, H., and Ghosh, S.K., 2011, J. Mol. Model., 17, 1091-1108.

13. Okano, K., Tsukube, H., and Hori, K., 2004, Tetrahedron, 60, 48, 10877-10882.

14. Diao, K.S., Wang, H.J., and Qiu, J.M., 2009, J. Mol. Struct. THEOCHEM, 901, 1-3, 157-162.

15. Diao, K.S., Bai, L.J., and Wang, H.J., 2011, Comput. Theor. Chem., 964, 1-3, 18-24.

16. Shamov, G.A., Schreckenbach, G., Martin, R.L., and Hay, P.J, 2008, Inorg. Chem., 47, 5, 14651475.

17. Hehre, W.J., 2003, A Guide to Molecular Mechanics and Quantum Chemical Calculations, Wavefunction, Inc., Irvine, CA, p. 72.

18. Jensen, M.P., Dzielawa, J.A., Ricket, P., and Dietz, M.L., 2002, J. Am. Chem. Soc., 124, 36, 1066410665.

19. Ansarifard, M., and Rounaghi, G., 2005, J. Inclusion Phenom. Macrocyclic Chem., 52, 1-2, 39-44.

20. Buschmann, H.J., Dong, H., and Schollmyer, E., 1993, J. Coord. Chem., 30, 3-4, 311-316. 